\title{
New Monetary System-Paradigm Changer
}

\author{
Ilija Lakicevic \\ Semedraž bb, 32300GornjiMilanovac, Serbia \\ teslastyle101@gmail.com
}

\begin{abstract}
A new monetary system based of time as standard of value and printing money with a one year of expiration date so that people would be inspired and motivated to get rid of money as quickly as possible by turning them into the real wealth (products and services) is considered as paradigm changer and possible solution for the transitional phase into civilization without money. This paradigm shift would enable the most efficient production of values depending on the unsupervised development and utilization of the freewill of conscious beings having the technological capabilities and economic-growth needs for which each additional, volitionally developed conscious being would be of immense, irreplaceable value.The new paradigm would also enable that all conscious beings live for rational happiness and its emotions of genuine self-esteem and love, fulfilling their moral purpose which is to meet the rational requirements of achieving true happiness.
\end{abstract}

Keywords: monetary system, standard of value, money, freedom, human happiness

\section{Introduction}

By the very fact of their continued existence, all civilizations technologically advanced significantly past their NuclearDecision Thresholds (which we now are) are free from the consciousness diseases of dishonesty (lie, cheating, stealing), mysticism (lack of knowledge), and irrationality (slavery to technology). Therefore we cannot enter into the Civilization of Universewith these characteristics - and thus it is necessary to learn and know beyondthose traits which are destructive to the ongoing consciousness of "human" (Higher Universal Man). A major dividing line in progressive soul expression comes at the Nuclear-Decision Threshold. A species in a given civilization will make it or break it, figuratively speaking, at that point. We are now very primitive in our evolvement -but technologically (in a physical way) to play with that which is non-physical and non-controllable from physical standpoint, to destroy the very manifestation of mankind as expressed in our experience. Pseudo-humans (human-copies or humanoids in whom the diseases of dishonesty and irrationality have destroyed the human nature of their consciousness) will notbe allowed into the Civilization of the Universe! They will be vanished - these false-humans will cease to exist!

WE cannot look into the next-moment with assurance or certainty - for it is only a perception as changeable as the Mind. Much the less can we in our limited bindings even begin to imagine the limitless expression of the technological states and economies of the advanced societiesthroughout the Civilization of the Universe.

Does this mean we should not seek out the wondrous advancement and expressions, luxuries and wealth of that which we are experiencing? No - it means that we must grow into realizing we can have those things and remain "Human" with all the attributes of goodly consciousness. The other aspects will be vanished!

No society or civilization, regardless of how advanced, can contradict the contextual laws of either physics or nature. Moreover, we can know that conscious beings throughout the Civilization of the Universe will never purposely violate their nature, well-being, and happiness. The basic nature of rational conscious beings has never and will never change. No rational being would ever let technology overtake his or her nature, self-control, self-responsibility, growth, and happiness. Because that loss of control over one's Self one's greatest value - would be irrational - the prime trait of a pseudo-human in anti-civilization. And, all conscious beings in the Civilization of the Universe are free of irrationality or any other impediments to individual consciousness, growth, and happiness.

It evolves, then, that all conscious beings in the Civilization of the Universe have the same nature: they all live for rational happiness and its emotions of genuine self-esteem and love. Indeed, the moral purpose of all conscious beings is to meet the rational requirements of achieving true happiness [1-26].

\section{The New Monetary System}

What is one real solution to the world financial crisis that benefits the people not the bankers and criminals?

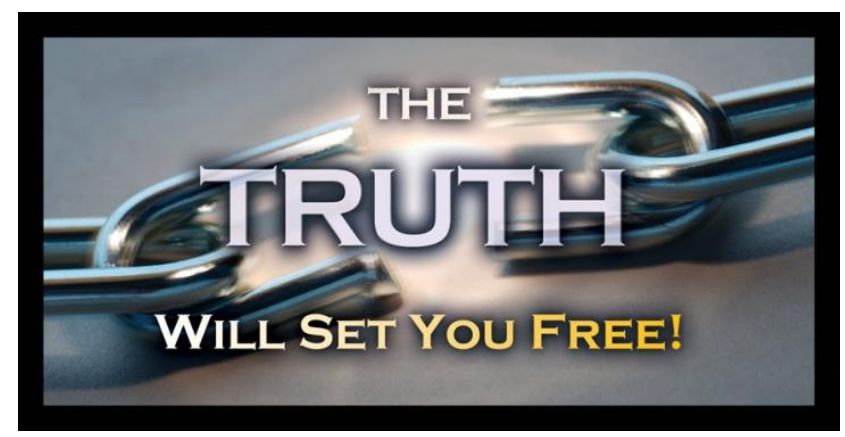

Figure 1: Truth is your Messiah

From THE REVELATOR, by Carl Gorton [27]: Quoting

\section{Defining the Monetary Problem}

The very first mandatory step in solving a challenge is to analyze it. Every challenge is a result, or effect, of a cause. The reason for analyzing a challenge is to determine its cause. When the cause of a challenge is clearly understood, the solution usually becomes obvious. Strangely, however, according to our monetary authorities and "experts" (has- 
been, drips under pressure), bankers, economists, investment brokers, politicians, etc., the subject of money is too mysterious for mere mortals to understand. Such things as the "business cycle", "inflation" and "depressions" are blamed on everything from consumer, producer and worker "greed" to the astrological (no relation to logical) position of the stars - ALWAYS ON USTHE-PEOPLE AS CAUSE OF WHATEVER FAILURE APPEARS.

Of all the incredible facts presented herein, perhaps the most incredible of all is that Americans, who take great pride in their technological achievements, swallow these bold-faced lies completely and swallow even the hook baited with poison. The fact of the matter is that money is a relatively SIMPLE SUBJECT and that business cycles are deliberately and scientifically created by and for the benefit of those who control our money. Nonetheless - the manipulation, historical evidence of the cycles are there for the viewing. The cycles have "cycled" enough times now to see the symptoms before the disease blossoms in fullness.

Inflation, depression and business cycles are symptoms, or effects, of a cause. What is the cause? The cause is an unstable supply of money with respect to the production of wealth! (A debt money system is inherently unstable.) Therefore, the solution is to provide an amount of money in circulation that is proportional to the production of wealth. This is relatively simple (if we do it before all production flees the nation) but there are several factors to be considered carefully. First, is the proper definition of some frequently misused words so that we have EXPLICIT DEFINITIONS REGARDING THAT WHICH WE SAY ACCORDING TO THAT WHICH WE UNDERSTAND! We define "MONEY" as a medium of exchange and a measure of value, regardless of the form which it may take. There are two major forms of money: commodity money (gold, silver, etc.) and created (or fiat) money. A commodity money system is actually a barter system of trading one commodity with a certain market value for another commodity or service with a certain market value. Incidentally, no commodity has "intrinsic" value, which only humans have. All commodity prices in a free market result from the law of "supply and demand". The price of gold, which is probably the most worthless of all metals for human use, is artificially established by the "gnomes" of London and Zurich, by which they control the economic health of every nation.

Created money is the only thing man can create. It is created out of nothing but paper and ink or computer bytes, but represents, or is a claim on, wealth. Created money is not wealth. Wealth is that which men produce for human use through the intelligent application of energy to natural resources. Fiat is a French word which means "So be it", and in operation applies to an order or edict by authority. ALL paper money is "fiat" money. However, as part of the ABs' (Anti-God Banksters) semantic subversion to control our thinking, "fiat" is used as a term of approbation, applied to government issued,debt-free money (U.S. Notes).

\section{Money: A Transportation System}

Money is the life-blood of society and performs the same function as blood does in our body, carrying food and oxygen to every cell and carrying away the waste products to sustain life. The blood system is actually a transportation system. Money may also be compared to a transportation system, as did Henry Ford:

"The function of money is not to make money but to move goods. Money is only one part of our transportation system. It moves goods from man to man. A dollar bill is like a postage stamp: it is no good unless it will move commodities between persons. If a postage stamp will not carry a letter, or money will not move goods, it is just the same as an engine that will not run. Someone will have to get out and fix it."

However, our "engine" was deliberately designed with a fatal flaw which causes it to self-destruct and it can NOT be "fixed". It must be replaced with another engine of proven design but with a modern control system that will enable it to have cruise-control that will enable it to "automatically" adjust to changing power requirements (money volume) in order to maintain a constant speed (money value). If we pursue this analogy further, the steps necessary to implement an honest and stable money system become obvious:

First, the unConstitutional and criminal Federal Reserve System must be abolished and its primary function, money creation, taken back by the Congress to whom it belongs, both logically and legally (Art. I, Sec. 8, U.S. Const.).

Second, the new engine, of proven design, must be a debtfree money system similar to the tally system of England, the scrip issued by the colonies and the U.S. Notes which enabled Lincoln to preserve the Union and which have saved American taxpayers over 100 BILLION dollars in usury which would have been stolen by the ABs.

Third, a Standard of Value for money must be established as a reference so that any deviation from it may be quickly detected and corrected. To our knowledge, there has never been a Standard of Value established for money in the history of man!

At this point many will object, thinking, "The Coinage Act of 1791 established a standard of value," or "The Gold Standard Act of 1900 established one." No. What these and the other monetary acts of Congress did was to establish a temporary standard of weight and purity of gold or silver coins called a "dollar".

Their "value" was determined in the market-place by vendors and buyers who bartered them for other commodities. In a relatively static, agricultural economy, they served quite well as money. That is, until the $\mathrm{ABs}$ cornered the market on gold, forced it upon the people as the "standard of money" and then, "removed gold from circulation, as far as possible". (Pro. \#20)

The myth that gold or a gold-based money system is the only way to provide stable money should have forever been put to rest when American nation suffered the worst financial panics and depression they ever endured between 
1900 and 1934 when they were on a "gold standard". However, suffice it to say that the IDEA behind the premise was good - but the actual manipulation destroyed the validity. Those who continue to promote this alternative today simply do so as either shrewd agents or ignorant (without knowledge) dupes of the ABs.Incidentally, the Pavlovian conditioning of the American sheeple became obvious in 1933 when they turned in their gold under orders from the ABs agent, FDR. (It will be interesting to see if the sheeple's grandchildren will turn in their guns when so ordered).

\section{The Standards for Standards}

One reason that a Standard of Value may never have been established is that it may have been considered impossible to do so. After all, every man values every thing differently from every other man and also differently at other times and places. Therefore, the first thing necessary to establish a 'Standard of Value' is to determine what the general requirements for all 'standards' are:

First, a standard must have similitude. That is, it must be similar to that which it measures. A standard of weight must have weight, a standard of length must have length, etc.

Second, a standard must have stability. That is, its value must remain constant under all conditions throughout the system which it serves. An inch is exactly the same length whenever and wherever it is used.

Third, a standard must have commonality. That is, everyone in the system must understand and have, or have easy access to, the standard unit. Most everyone in America knows what an inch is and has, or can easily obtain a rule (standard) with which to exactly measure it.

\section{Gold fails as a Monetary Standard}

Now, if we compare any commodity, and most especially gold, against these criteria for a monetary standard with which to measure wealth, we find them to be woefully inadequate.

With respect to the first criterion, similitude, there is no relationship whatsoever. The value of gold is determined by its weight and purity. While the price of many commodities (coal, wheat, meat, fruit) is determined by weight, the price of manufactured goods bears little, if any, relationship to their weight, the major cost factor being that of "labor".

With respect to the second criterion, stability, we find that gold is only chemically stable, that is, durable. (Is it possible that this word might derive from the Plain of Dura, where the King of Babylon, Nebuchadnezzar, first established the Gold Standard?) As a commodity in a free market its price would vary in accordance with the law of "supply and demand". As a controlled commodity, its price has been less stable than that of the stock market, and for the very same reasons.

With respect to the third criterion, commonality, while many people have gold wedding rings and some have gold fillings, very few have any gold coins which could be used as money.

Furthermore, the vast majority of the worlds' gold is owned or controlled by the ABs. Think about that.

Thus, it is obvious that of these three criteria for ALL standards of measurement, gold and silver meet none of them as a monetary standard.

Incidentally, the "gold bugs" insist that money, in addition to serving as a medium of exchange and measure of value, must also be a store of value, which most of them erroneously refer to as "intrinsic" value. But these are contradictory requirements. Money, in order to serve its function as a medium of exchange, must be kept in circulation and the faster it circulates (called "V" for "velocity") the better it serves that function. If it is "saved" or hoarded, it cannot function as a medium of exchange. This is the reason for the need to continually mint large quantities of pennies, because many people fill jars or "piggy banks" with them as a form of saving, often using them as convenient door stops as the jar fills. A better store of value would be gold. But the best are, in order of priority: STORAGE FOOD, WATER, FUEL, SEEDS, TOOLS AND SILVER COINS.

\section{Time is Money}

Since no commodity has all of the criteria to serve as a monetary Standard of Value, what in the world does? A clue to what this might be is given in Revelation 18:12, 13, which lists the treasures of end-time Babylon in descending order of value. The first are "cargoes of gold and silver" and the last are "slaves and human lives". Yes, the lives of men are the least valuable thing in Babylon. Does this not prove that we live under Babylonian rule today, when we send our finest young men to fight, suffer and die in the ABs' no-win wars and, even worse, permit helpless, unborn babies to be murdered by the millions?

If the Babylonian system is to be overthrown, then its value system must be reversed. Instead of everything being measured by gold or silver, the proper standard should be the lives of men. And how are the lives of men measured? By "TIME"! Yes, the perfect standard of value can be established based upon the time of men's lives, or manhours of work.

The price of all things can be, and frequently is, based upon the man-hours of labor required to make them and market them. The price of something is often quoted in terms of the average man-hours of labor required to purchase it, especially in comparisons between different nations or time periods. In fact, this is the conscious or unconscious means by which everyone determines the value of anything to himself; how much of his life "time" must he exchange for it? Most everyone is already aware of the fact that "Time IS MONEY".

\section{A True Standard of Value}

Let us arbitrarily establish our monetary standard as one 
average man-hour of labor, which would be equivalent to setting the cruise-control at, say, $60 \mathrm{mph}$. This new standard of monetary value should also have a name, so let us call it a "Manny" and its 1\% division a "Minny", for obvious reasons.

How well does a Manny meet the requirements for a standard? Let us compare them and see. First, similitude. Labor time is the primary factor in determining the price of everything and also the value of everything to each person, as already mentioned. Second, stability. There is nothing more stable than time, which remains fixed through all generations and nations. Third, commonality. Nothing is more common among men than time, which is distributed to all men equally; 24 hours a day.

Everyone understands time and virtually everyone has its standard of measurement on his wrist - a watch. We measure and regulate our lives by "time". This paper, for example. A dollar value cannot be placed on the work required to write it (which was about ten times longer than expected) nor on the many years required to study, research analyze, understand, and solve the problem. The only cost that can be placed on the effort is the time involved to accomplish it. Thus, we find that the Manny not only meets all of the requirements for standards in general, but uniquely serves as a monetary Standard of Value.

\section{How Manny Money Functions}

The Manny system may be instituted by any taxing authority anywhere in the world and trade could be conducted with any other Manny-based economy at par, since all Mannys would be issued against the same standard.

The taxing and money-issuing authority would print, with a one year expiration date, as many Mannys as necessary to meet its authorized expenditures. These would be paid into circulation as wages to government employees and to contractors for goods and services. The AWARAGE wage paid would be maintained at the rate of 1 Manny/hr.

How? Very simply. For government employees, the actual average wage paid is determined by dividing the total wages earned by all employees by the total hours worked by all employees. If the result is more or less than one, the pay rate would be adjusted accordingly. For instance, if there are $1,000,000$ man-hours in one week and their wages totaled "O"39,604,000, then each employee's actual pay would be increased $1 \%$ to maintain the standard of $1 \mathrm{Manny} / \mathrm{hr}$. Actual individual wages might range from 40 $\mathrm{o}$ (Minnie)/hr. to $4 \mathrm{O}$ (Manny)/hr., more or less.

This direct adjustment in pay would be fine for government employees, but what about those who are employed by business and professional and self-employed people? The earnings of entrepreneurs and professionals would not enter into the balance equation since that is confidential. The average wage of employees would be obtained from every employer doing business in the nation and the overall average wage easily calculated. If this figure varied from the standard, the government would increase or decrease its spending to maintain the standard.
With the Manny system, taxation to pay for government expenditures would not be necessary, since the government would print all the money necessary. However, money must be removed from circulation at a rate equivalent to its being spent into circulation or its volume would continue to increase until it became worthless (inflation).

With the Manny system the removal, or taxation could be the ultimate in equity and simplicity. As previously stated, the Mannys would be printed with a one-year expiration date, after which they would become worth-less. However, they could be turned in to the tax collector within thirty days after they expired, for new Mannys which would be good for another year. However, the new Mannys issued would only be $90 \%$ (or other percentage determined by the taxing authority) of those turned in.

Practically all of the expired Mannys would be exchanged by businesses in relatively large volumes rather than by individuals, who would spend their about-to-expire Mannys, thus enhancing trade. Hence, most taxes would be paid by business in proportion to their profits and no income tax computations or payments would be required from anyone.Mannys which were lost or destroyed would accrue to the benefit of everyone since they would not be redeemed by the tax collector for new Mannys.

Anyone convicted of tampering with the Manny System, whether government employee, business employee or counterfeiter, should be sentenced to life working for the community with all other felons. Adoption of the MannyMinny system would produce numerous benefits:

1) A stable money system based on a Standard of Value which everyone understands.

2) Elimination of the present legalized system of organized crime, theft and slavery through usury.

3) Reduction of the tax burden by eliminating the income tax and the IRS. (The IRS is the U.S. government agency responsible for tax collection and tax law enforcement.)

4) No involuntary unemployment since ample money would be available to pay for labor that is available to do any needed job.

\section{End of Quoting}

Let me at this point quote God Aton/Hatonn:

"I find that it is important that this author be contacted and consideration of this approach as outlaid be considered most carefully. It can be more easily understood directly from the presenter - I HAVE NO INTEREST IN YOUR MONEY MATTERS OTHER THAN TO GET YOU STABILIZED SO WE CAN GET YOU HOME IN WHOLENESS. THESE ARE THE THINGS OF POLITICAL PHYSICAL EXPERIENCE BUT MUST BE DEALT WITH IF YOU ARE TO RECLAIM FREEDOM WHICH, IN TURN, MEANS FREEDOM OF SOUL. LET US CONSIDER THIS JOURNEY AND THESE POSSIBILITIES MOST CAREFULLY."

The author in point, Carl Gorton, can be contacted by writing The Revelator, Christian American Research 
League, C/O. Box 911, Cocoa, Florida 32922.

\section{Paradigm Change}

In my opinion money is an energy which serves our creative expression. The main feature of energy is that energy seeks to move. Energy does not like to get stuck and whenever it happens energy attracts and creates some outer conditions in order to get moved. It is the rule which is valid as on personal level as well on civilization or cosmic level. The nicest examples which prove this rule are all the empires through the evolution of the mankind on this planet. All the empires have created strict rules and laws in order to control and manipulate everything creating at the same their own destruction because the stuck energy attracted and created some outer conditions (mainly wars and big cataclysmic events) which finally destroyed the empire and energy continued to move seeking new expressions. In other words all empires have been self-destructed.

In the old paradigm people have been striving to have as much money as possible whereas the money mostly sit idle on bank accounts or in some safes which is actually stuck energy as a potential danger. But, having in Mind what is money and knowing the energy essence it is obvious that we have to strive to create such a monetary system which will enable very quick energy motion - means very fast money transmission into products and services. That would provide the new paradigm where people would compete to get rid of money as quickly as possible by transmuting money into products and services - into wealth. In the new paradigm people would be inspired and motivated to increase their own creativity contributing in that way to their own wealth and to the common wealth of the civilization.

I'd accept and support this new paradigm for the transitional phase into a civilization without money.

In any rational civilization, overpopulation and aging are impossible. Exactly the opposite occurs. When free of destructive humanoids, each conscious being is free to productively, culturally, and artistically innovate and flourish without limits, becoming a priceless value to others and society. For, each conscious being in a rationalcivilization innovates and produces through division-of-labor dynamics far more values and resources than he or she consumes. This is always an increasing in value, with entropy never increasing, and conscious beings remain forever young for there is no "age" consideration.

In the never-ending Civilization of the Universe, a great demand for volitional conscious beings always exists. When free in an open and rational society based on objective law, each conscious being enormously benefits and enriches all other conscious beings. Through and throughout eternity, therefore, each conscious being will contribute more value to society than its entire population at any given point of time.

Knowledge and technology increase endlessly. All advancing civilizations require developing ever greater and cheaper energy sources and production efficiencies.
Prosperity and happiness of conscious beings do notdepend on their actual level of knowledge or technology, but on their rational thinking and acting processes required for continuously advancing knowledge, technology, and beauty from any level.

Throughout the universe, every level of advancing knowledge and technology exists. Thus exists a technological level of conscious beings whose most efficient production of values depends on the unsupervised development and utilization of freewillof conscious beings having the technological capabilities and economic-growth needs for which each additional, volitionally developed conscious being would be of immense, irreplaceable value. Thus, honest conscious beings anywhere in existence are never allowed to perish. So my suggestion is to always travel in the correct direction and remain both conscious and honest.

\section{Conclusions}

In order to enter civilization of Universe where evil is not allowed, we human beings must heal the heavy consciousness diseases of our anti-civilization: dishonesty (lie, cheating and stealing), mysticism (lack of knowledge) and irrationality (slavery to technology).

Besides that, the Creator God's Love Principle of equal giving and regiving - Rhythmic Balanced Interchange in all human transactions - must be obeyed without exceptions.

A one way to fulfill these strict requirements is to replace gold as standard of value with time as value standard and print money with a one year of expiration date so that people would be inspired and motivated to get rid of money as quickly as possible and transfer them into real wealth products and services.

This paradigm shift would enable that prosperity and happiness of conscious beings would depend on their rational thinking and acting processes required for continuously advancing knowledge, technology, and beauty from any level. It would also enable a technological level of conscious beings whose most efficient production of values depends on the unsupervised development and utilization of theirfreewill having the technological capabilities and economic-growth needs for which each additional, volitionally developed conscious being would be of immense, irreplaceable value.

The new paradigm wouldalso enablethat all conscious beings live for rational happiness and its emotions of genuine self-esteem and love, fulfilling their moral purpose which is to meet the rational requirements of achieving true happiness.

\section{References}

[1] Ilija Lakicevic, ""Aton" True Cell, Atom and Particle Concept", International Journal of Science and Research (IJSR), https://ijsr.net/archive/v8i10/show_abstract.php?id=A 
RT20201755, Volume 8 Issue 10, October 2019, 388 395

[2] Ilija Lakicevic, "The True Concepts, Laws and Equations of Creation", International Journal of Science and Research (IJSR), https://www.ijsr.net/archive/v8i10/show_abstr act.php?id=ART20202091, Volume 8 Issue 10, October 2019, $1170-1193$

[3] Ilija Lakicevic, "The Right Therapy for Radiation Poisoning", International Journal of Science and Research (IJSR),

https://www.ijsr.net/search_index_results_pape rid.php?id=SR20309224250, Volume 9 Issue 3, March 2020, $568-575$

[4] Ilija Lakicevic, "The True Value of the PI Number and Squaring the Circle", International Journal of Science and Research

(IJSR), https://www.ijsr.net/search_index_results_pape rid.php?id=SR20409190322, Volume 9 Issue 4, April 2020, $624-633$

[5] Ilija Lakicevic, "Birth of the Planetary Being", International Journal of Science and Research (IJSR), https://www.ijsr.net/search_index_results_pape rid.php?id=SR20422181950, Volume 9 Issue 4, April 2020, 1148 - 1164

[6] Ilija Lakicevic, "Atom, Electric Current, Gravity, Magnetism, Energy, Mass and Speed of Light are NOT what Science believes and Earth is NOT a Magnet", International Journal of Science and Research (IJSR), https://www.ijsr.net/search_index_results_pape rid.php?id=SR20427191555, Volume 9 Issue 4, April 2020, $1534-1543$

[7] Ilija Lakicevic, "The True Nature of the Electricity and Secret of Motion, Matter and Inert Gases", International Journal of Science and Research (IJSR), https://www.ijsr.net/search_index_results_paper id.php?id=SR20502204916, Volume 9 Issue 5, May 2020, $239-252$

[8] Ilija Lakicevic, "Collective Responsibility for our Current Circumstances", International Journal of Science and Research (IJSR), https://www.ijsr.net/search_index_results_paper id.php?id=SR20520184548, Volume 9 Issue 5, May $2020,1368-1374$

[9] Ilija Lakicevic, "What is Light?", International Journal of Science and Research (IJSR), https://www.ijsr.net/search_index_results_pape rid.php?id=SR20527215002, Volume 9 Issue 5, May $2020,1644-1653$

[10] Ilija Lakicevic, "Shaking Science's Foundations Walter Russell Won Approval 90 Years Ago", International Journal of Science and Research (IJSR), https://www.ijsr.net/search_index_results_pape rid.php?id=SR20531180317, Volume 9 Issue 6, June 2020, $121-137$

[11] Russell Walter: "The Universal One" Edited by Louise Russell, UNIVERSITY OF SCIENCE AND PHILOSOPHY Swannanoa, Waynesboro, Virginia

[12] Russell Walter: "The Secret of Light", Third Edition, UNIVERSITY OF SCIENCE AND PHILOSOPHY, FORMERLY THE WALTER RUSSELL FOUNDATION SWANNANOA, WAYNESBORO, VIRGINIA22980
[13] Russell Walter and Lao: “Atomic Suicide?” Copyright 1957, 3rd EDITION: 304 Pages, ISBN: 978-1-87960511-4

[14] GYEORGOS CERES HATONN "dharma", PHOENIX JOURNAL: "MATTER ANTI-MATTER \& WHAT'S THE MATTER" ISBN 0-922356-41-6, First Edition Printed by America West Publishers, 1991, Published by AMERICA WEST PUBLISHERS, P.O. B0X 986, Tehachapi, CA. 93581

[15] GYEORGOS CERES HATONN "dharma", PHOENIX JOURNAL: "GOD ATON SAID: LET THERE BE LICHT AND CREATION BECAME", PLEIADES CONNECTION, VOL.II, ISBN 0-92235642-4, First Edition Printed by America West Publishers, 1991, Published by AMERICA WEST PUBLISHERS, P.O. B0X 986, Tehachapi, CA.93581

[16] VIOLINIO GERMAIN \& GYEORGOS CERES HATONN "dharma"e, PHOENIX JOURNAL: "I AND MY FATHER ARE ONE SECRETS OF UNIVERSAL ORDER: ETERNAL QUEST OF MAN", PLEIADES CONNECTIONVOL.III, 17.ISBN 0-922356-46-7, First Edition Printed by America West Publishers, 1991, Published by AMERICA WEST PUBLISHERS, P.O. B0X 986, Tehachapi, CA. 93581

[17] VIOLINIO GERMAIN \& GYEORGOS CERES HATONN/ATON "dharma", PHOENIX JOURNAL: "MURDER BY ATOMIC SUICIDE Technical And Spiritual Disclosure Of The Secrets Of How, Why, What, Where, When And Who Of The Universe And Its Functional Projections", PLEIADES CONNECTION VOL. IV, ISBN 0-922356-47-5, First Edition Printed by America West Publishers, 1991, Published by AMERICA WEST PUBLISHERS, P.O. B0X 986,Tehachapi, CA. 93581

[18] VIOLINIO GERMAIN \& GYEORGOS CERES HATON /ATON "dharma"e, PHOENIX JOURNAL: "PHONE HOME ET. REACH OUT AND TOUCH SOMEONE LIKE GOD ATON!", PLEIADES CONNECTION VOL. V, ISBN 0-922356-48-3, First Edition Printed by America West Publishers, 1991, Published by AMERICA WEST PUBLISHERS, P.O. B0X 986, Tehachapi, CA. 93581

[19] VIOLINIO GERMAIN \& GYEORGOS CERES HATONN/ATON "dharma", PHOENIX JOURNAL: "THE SACRED SPIRIT WITHIN MITAKUYEOYASIN (for all my relations--which is ALL)", PLEIADES CONNECTION VOL. VI, ISBN 0- 922356-50-5, First Edition Printed by America West Publishers, 1991, Published by AMERICA WEST PUBLISHERS, P.O. BOX 986,Tehachapi, CA. 93581

[20] VIOLINIO GERMAIN \& GYEORGOS CERES HATONN/ATON "dharma", PHOENIX JOURNAL: "HUMAN THE SCIENCE OF MAN THE SCIENTIFIC DEFINITION AND PROOF OF GOD ATON AND THE COSMIC ORDER OF THE UNIVERSE WHAT IS CREATION AND HOW IT CAME TO BE", PLEIADES CONNECTION VOL. VII, ISBN 0- 922356-51-3, First Edition Printed byAmerica West Publishers, 1991, Published by AMERICA WEST PUBLISHERS, P.O. B0X 986, Tehachapi, CA.93581

[21] VIOLINIO GERMAIN \& GYEORGOS CERES HATONN/ATON "dharma", PHOENIX JOURNAL: 
"SCIENCE OF THE COSMOS TRANSFORMATION OF MAN", PLEIADES CONNECTION VOL. VIII, ISBN 0-922356-52-1, First Edition Printed by America West Publishers, 1991, Published by AMERICA WEST Licensed Under Creative Commons Attribution CC BY PUBLISHERS, P.O. B0X 986, Tehachapi, CA. 93581

[22] GYEORGOS CERES HATONN, PHOENIX JOURNAL: "MYSTERIES OF RADIANCE UNFOLDED", RELATIVE CONNECTIONS VOL.II, ISBN 1-56935-019-1, First Edition Printed by PHOENIX SOURCE PUBLISHERS, Inc. P.O. Box 27353, Las Vegas, Nevada 89126, August 1993

[23] GYEORGOS C. HATONN: "PHOENIX OPERATOR-OWNER MANUAL" ISBN 1-56935018-3 Third Edition Printed by PHOENIX SOURCE PUBLISHERS, Inc. P.O. Box 27353 Las Vegas, Nevada 89126 August 1993

[24] SANANDA \& JUDAS ISCARIOTH "AND THEY CALLED HIS NAME IMMANUEL" I AM SANANDA ISBN 1-56935-014-0 Third Edition Printed by PHOENIX SOURCE PUBLISHERS, Inc. P.O. Box 27353 Las Vegas, Nevada 89126 August 1993

[25] GYEORGOS CERES HATONN, PHOENIX JOURNAL: "FIRST STEPS", ISBN 1-56935-057-4, First Edition Printed by PHOENIX SOURCE PUBLISHERS, Inc. P.O. Box 27353 Las Vegas, Nevada 89126, September 1995

[26] GYEORGOS CERES HATONN, PHOENIX JOURNAL: "IF THERE BE "WILL" THERE BE "WAY"”, TANGLED WEBS VOL.IX, ISBN 0922356-84-X, First Edition Printed by America West Publishers, August 1992 